\title{
A historical morphology of Western Karaim: The -a jez- $\sim-a$ ez- approximative
}

\author{
MICHAŁ NÉMETH*
}

Faculty of Philology, Jagiellonian University in Kraków

al. Mickiewicza 3, room 201,31-120 Kraków, Poland

Received: June 30, 2020 • Accepted: November 22, 2020

(c) 2021 The Author

\section{ABSTRACT}

Karaim is often treated as an exceptional Kipchak Turkic tongue in which certain, otherwise widespread Turkic verbal constructions are not present. Philological discoveries of recent years show, however, that some of these categories did exist in Karaim. As a response to this issue, the present article documents the Western Karaim equivalent of the Tkc. - a jaz- approximative construction. It is based on $18^{\text {th }}$ - and $19^{\text {th }}$ century Biblical texts which are then juxtaposed with both phonetically and morphologically atypical $20^{\text {th }}$ century data. This contribution is part of a series of works describing Karaim grammatical categories hitherto undocumented in the scholarly literature.

\section{KEYWORDS}

historical morphology, Western Karaim, the Turkic - $a+$ jaz-approximative, historical morphology of Kipchak

*Corresponding author. E-mail: michal.nemeth@uj.edu.pl 


\section{INTRODUCTORY REMARKS}

A historical grammar of Karaim - a Kipchak Turkic vernacular listed as a critically endangered tongue in the UNESCO Atlas of the World's Languages in Danger - has been a desideratum up until the present day. The reason for this lies in the fact that even just a decade ago the oldest known and properly edited Western Karaim texts dated from no earlier than 1900, whereas for decades, as far as Eastern (Crimean) Karaim is concerned, the only descriptions based on sources older than 1900 were Józef Sulimowicz's $(1972,1973)$ study of the lexicon and phonology of a printed prayer book and Henryk Jankowski’s (1997) grammatical description of a Biblical manuscript in which extensive linguistic material is presented. Therefore, the existing grammatical descriptions - be it academic grammars, scholarly journal articles devoted to specific grammatical phenomena, or works in which linguistic remarks are presented marginally - lacked a properly documented historical perspective. ${ }^{1}$ In fact, our philologically documented knowledge of the pre- $19^{\text {th }}$-century history of Karaim dialects was based only upon reconstructions. ${ }^{2}$ Fortunately, the last decade has seen the discovery of numerous Karaim sources from the $17^{\text {th }}$ and $18^{\text {th }}$ centuries, see Jankowski (2014), Jankowski et al. (2019), and Németh (2014, 2015c, 2016, 2018a, 2020,2021 ), which opens up new avenues of research and gives us the opportunity, on the one hand, to verify the existing reconstructions and, on the other, to augment our knowledge of the pre- $19^{\text {th }}$-century history of Western Karaim. ${ }^{3}$

Several years ago, we began work on a series of articles that presented hitherto undocumented Western Karaim grammatical categories. Their apparent lack helped create an incomplete picture of this language in the scholarly literature: Karaim is often treated as an exceptional Kipchak Turkic tongue in which certain, otherwise widespread verbal constructions are not present. Bearing this in mind, in Németh (2015a, and 2019) we documented and performed a contrastive anal$y$ sis of the $-p$ edi pluperfect and the $-a d y r$ continuative present, which were often described as non-existent in Karaim, see, for instance, Berta's (1998: 311) description in which we read that 'all languages except Karaim also use a more focal present to express events currently taking place [...] mostly formed with the - $A$ converb + auxiliary verb tur-'stand' + pronominal personal markers [...]'. Other works worth noting in this respect are Johanson's (1999: 173) article in which the author remarked that 'all Kipchak languages except Karaim possess numerous actional specifiers signalling modes of action, postverbial constructions consisting of a converb marker plus a following auxiliary, often a postural verb', or Schönig's (1984: 303) seminal work, in which it is stated that Karaim and Gagauz are the only Turkic languages in which there are no auxiliary verbs like the ones mentioned above. The above opinions were, we should emphasize once again, a result of the absence of a representative number of Western Karaim written sources available to scholars.

The present paper is a continuation of the above-mentioned series of articles and it is the Western Karaim - $a$ jez- $\sim-a$ ez-construction that is under scrutiny here.

\footnotetext{
1 See Kowalski 1929, Zajączkowski 1931, Pritsak 1959, Musaev 1964, 1977, Prik 1976, Firkovičius 1996, Berta 1998, Aqtay 2009: I: 33-47, Németh 2011a: 21-76, 2011b, Olach 2013, and Gülsevin 2016: 49-131. Karaim wordformation was presented by Zajączkowski (1931: 20-23; 1932) and Çulha (2006: 18-32).

2 To provide the full details of this picture, we ought to mention that some descriptions of Karaim have been complemented with historical remarks, but these were usually marginal commentaries. A good example is Musaev's (1964) grammar: it contains many observations of this kind, but without specifying the sources they are based on. 3 We refer to this period as Middle Western Karaim; for the first periodization of Western Karaim, prepared on the basis of phonological, morphonological, and historical criteria, see Németh 2015c, 2018 b.
} 


\section{TURKIC COMPARATIVE MATERIAL}

The analysed verbal form is known from a number of Turkic languages and consists of the Tkc. $-a$ converbial form of the main verb used in conjunction with the common Turkic (main and auxiliary) verb jaz- 'to miss (Germ. verfehlen), to fail, to err' < PTkc. ${ }^{\star} j a \bar{z}$ - (ĖSTJa 1989: 72-73) possibly related to PTkc. ${ }^{\star} \bar{a} z$ - 'to get lost, to lose one's way' (ĖSTJa 1974: 94-95). ${ }^{4}$ In all the respective Turkic languages the construction is (or was) used to express an action that has almost taken place. It is well-documented in the Kipchak branch of the Turkic languages, see, for instance, Bshk. - a jaz(Juldašev 1981: 222), Tat. - a jaz- (Poppe 1961: 102), CTat. - a jaz- (Jankowski 1992: 175, Jankowski 2010: 137), Nog. - a jaz- (Csató \& Karakoç 1998: 338), Kirg. -a žazda- (KirgRussS 1965: 212), KzK. - a žazda- (Muhamedowa 2016: 146-149), or Kklp. - a žaz- (Baskakov 1952: 376). ${ }^{5}$ It is also known from Middle Kipchak sources, see Zajączkowski (1954: 56) or Clauson (1972: 984). In Codex Comanicus (a $14^{\text {th }}$-century Kipchak Turkic manuscript written by several hands in Latin script) the verb jaz- 'to miss' is attested once (Drimba 2000: folio $57 \mathrm{r}^{\circ}$ ), but not in the role of an auxiliary verb (von Gabain [1959] does not document the auxiliary jaz-, either), see «urdim da iazdim〉 urdym da jazdym 'I struck and missed' (Kuun 1880: 134, 254; Radloff 1887: 40).

It is also used outside the Kipchak group, see e.g. Tksh. - a jaz- (Kononov 1956: 211-212;), Uyg. - a jaz- (Nadžip 1960: 85, 87), Uzb. - a jåz- (Wurm 1959: 520), or Alt. -a jasta- (Rachmatullin 1928: 24; not noted in Baskakov [1947]). ${ }^{6}$ Additionally, as far as the historical varieties of Turkic are concerned, it is known to perform the same role in Ottoman Turkish (see Kerslake 1998: 191), Chagatay (see Eckmann 1966: 145; not noted either by Blagova [1994] or Bodrogligeti [2001]), and Old Turkic (DTS 250, s.v. jaz-III) - recorded in the $11^{\text {th }}$-century dictionary of Mahmūd alKāšgarī (Dankoff \& Kelly 1985: 220). We might add here that, as far as Old Turkic is concerned, Clauson (1972: 983) and Erdal (2004: 260) deliver a somewhat more elaborate and convincing interpretation of the analysed construction (than the one available in DTS), namely that it denoted actions which the subject failed to carry out.

\footnotetext{
${ }^{4}$ This is, obviously, a simplified description of this verbal construction: the set of allophones of the Tkc. $-a \sim-e$ $(-\ddot{a}) \sim-j$ converb as well as the phonetic shape or morphological structure of the equivalents of Tkc. jaz-vary in the respective Turkic languages. A comprehensive overview of the Turkic reflexes of the - $a$ converb is presented in the table added to Džanmavov's (1967) study.

${ }^{5}$ In Kazakh and Kirghiz another construction is also employed to express the same meaning: the respective cognates of the above-mentioned Tkc. jaz- 'to miss' are used with the - $a$ converbial form of a second auxiliary verb (ket- 'to go', kal- 'to stay', or koj- 'to put') that follows the - $p$ converbial form of the main verb, i.e.: Kzk. $-p$ kete $\sim$ kala $\sim$ koja žazda- (Somfai Kara 2002: 49-50), and Kirg. -p kete $\sim$ kala kojo žazda- (Somfai Kara 2003: 55; not noted in some other grammars, see Wurm 1949; Hebert \& Poppe 1963), e.g. Kirg. ölüp kala 亏̌azdady 'he almost died' $\leftarrow$ öl- 'to die'.

${ }^{6}$ Juldašev (1965: 109-111) provides only Bashkir, Tatar, and Uzbek examples of the analysed construction, Räsänen (1957: 185) documents only Tatar, Karakalpak, Uzbek, Turkish, and Oyrot (Altay) data, Räsänen (1969: 193, s.v. jaz 'fast tun, anfangen zu tun') mentions only its Chagatay, Ottoman, and Tatar cognates, after Radloff (1905: III/1: 227).
} 


\section{THE AVAILABLE WESTERN KARAIM DATA}

\subsection{Description of primary sources}

The Western Karaim material presented in this paper is excerpted mainly from translations of the Torah. The basis of our work was the text of ms. ADub.III.73 which contains the oldest known translation, made in 1720, into Western Karaim, more precisely its north-western dialect. A comprehensive critical edition of this text was published by Németh (2021). The verses in which we found the analysed examples were checked against another $18^{\text {th }}$-century North Western Karaim manuscript, namely TKow.01 (created in 1722), as well as against ms. JSul.III.01, a mid-19 $9^{\text {th }}$-century South-Western Karaim translation of the Torah. Finally, an additional text taken into consideration was the revised translation of the Book of Genesis published in Vilnius by Mickiewicz and Rojecki in 1889.

It is important to note that we have at our disposal the historical and philological data necessary to establish the time and place where the above-mentioned sources were created. Manuscripts ADub.III.73 and TKow.01 were copied in Kukizów (a small settlement in present-day Western Ukraine) by a person called Simcha, son of Chananel of Derażne (born in Trakai ca. 1670). He moved to Kukizów in 1688, where he was the hazzan (i.e., head priest) from ca. 1709 until his death on 27 March 1723. He began work on ADub.III.73 on 25 March 1720 and finished it on 31 May 1720 (as specified in the colophon on folios $342 \mathrm{r}^{\circ}-342 \mathrm{v}^{\circ}$ ). Roughly two years later, he commenced work on ms. TKow.01 which he finished copying on 7 December 1722. ${ }^{7}$ Ms. JSul.III.01, in turn, was copied in Halych most probably not later than the mid $19^{\text {th }}$ century. It is the work of Jeshua Josef Mordkowicz, a copyist, translator, and hazzan in Halych (born 1802, died 23 July 1884). His South-Western Karaim idiolect was described in detail by Németh (2020: 46-47), and a short sample of this manuscript was presented by Cegiołka (2019). The North-Western Karaim translation of the Book of Genesis prepared for printing by Mickiewicz and Rojecki (1889) originates from the $19^{\text {th }}$ century. Examples $(1 \mathrm{a}-\mathrm{c})$, and $(2 \mathrm{a}-\mathrm{d})$ were excerpted from the sources above.

Example (3) was found in the theatre play entitled Dostu juvńuń [= 'Family friend'] authored by Szymon Firkowicz (1897-1982), the hazzan in Trakai, a native-speaker of North-Western Karaim. The play was published by Kowalski (1929: 117) in a phonetic transcription. Exactly the same word was adduced by Zajączkowski (1932: 65).

The present author was fortunate enough to identify three other examples $(4 a-c)$ of the analysed construction written in pencil by Józef Sulimowicz (1913-1973), a Karaim-born Turkologist and native-speaker of South Western Karaim. A short annotation of his was found in the bottom margin of page 27 of A. Zajączkowski’s concise grammar of South-Western Karaim (i.e., Zajączkowski 1931). The copy of the book in question was the property of Józef Sulimowicz and it was bound together with a copy of Zajączkowski's study on Western Karaim word formation (i.e., Zajączkowski 1932). ${ }^{8}$ The latter book was signed by the author as proof of ownership, but it later entered into the possession of Józef Sulimowicz. The handwriting of the notes in question

\footnotetext{
7 For more information regarding Simcha ben Chananel and mss. ADub.III.73 and TKow.01, see Németh (2020, 2021).

8 The book cover is decorated with the Polish word Sufiksy imprinted in gold Art Deco style letters. The latter suggests that the two works could have been bound together in the interwar period - either by Zajączkowski or by Sulimowicz. The present author received this item years ago as a gift from Anna Sulimowicz-Keruth.
} 
is identical to that found in Sulimowicz (1969), a notebook that the present author used, among other sources, for the preparation of Németh (2015a). It was also recognized by Anna Sulimowicz-Keruth, Józef Sulimowicz's daughter, as her father's handwriting.

No Eastern Karaim examples of this construction were identified thus far.

\subsection{Technical remarks on the glosses}

In the interlinear morpheme-by-morpheme glossing presented below the auxiliary verb in question (which is only one component of the analysed construction) is, at this point tentatively, labelled as a grammatical marker (APRX) rather than a separate lexeme. Derivative suffixes and petrified (non-productive) morphemes are not labelled. Eng. arch. thou and Eng. you are used to distinguish between the two modern meanings of you. The Biblical context was checked against Benson (1857), Peake (1920), and Friedman (2003). The transcription system applied here was presented in detail by Németh (2020: 56-59, 99-104). Its main advantage is that it reconciles the phonological, phonetic, and phonotactic peculiarities of the Middle Western Karaim and Modern Western Karaim dialects.

\subsection{Western Karaim linguistic data}

(1) keltirejezdij (Genesis 20:9)

a. Da ündedi Avimeleh Avrahamny da ajtty anar ne qyldyj bizǵa da ne jazyqly boldum saja ki k e l t $\boldsymbol{i}$ r e j e $\boldsymbol{z} \boldsymbol{d} \boldsymbol{i} \boldsymbol{j}$ üstüma da bijligim üstüńa ullu jazyq išlar ki qylynmajdylar qyldyj birgema. (ADub.III.73: $28 \mathrm{r}^{\circ}$ )

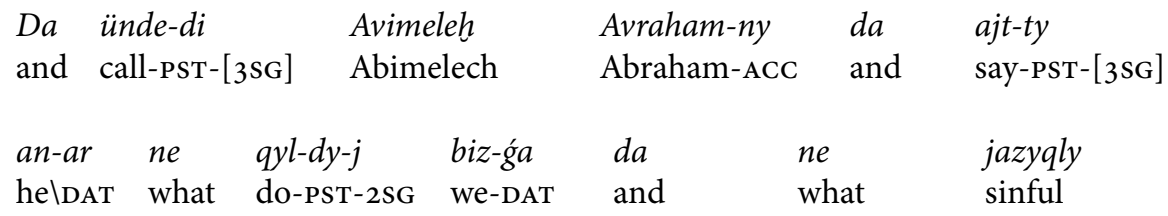

$\begin{array}{lllll}b o l-d u-m & s a j-a & k i & \text { keltir- } \boldsymbol{e}=\mathbf{j e z}-\boldsymbol{d i}-\mathbf{j} & \ddot{u} s t-\ddot{u} m-a \\ \text { be-PST-1SG } & \text { thoulDAT } & \text { that } & \text { bring-CONV=APRX-PST-2SG } & \text { top-1SG.POSs-POSS.DAT }\end{array}$

$\begin{array}{lllll}d a & \text { bijlig-im } & \text { üst-üń- } a & \text { ullu jazyq } \\ \text { and } & \text { kingdom\1sG.Poss } & \text { top-3sG.POss-Poss.DAT } & \text { great } & \text { sin }\end{array}$

$\begin{array}{llll}i \check{\text { š-lar }} & k i & \text { qylyn-ma-j-dylar } & q y l-d y-j \\ \text { matter-PL } & \text { which } & \text { be.done-NEG-PRS-3PL } & \text { do-PST-2SG }\end{array}$

birge-ḿ- $a$.

with-1SG.POSS-POSS.DAT 
'And Abimelech called Abraham, and said to him, "What have you done to us? And how did I sin against you, that you have almost brought a great sin on me and on my kingdom? You have done things with me that are not done."

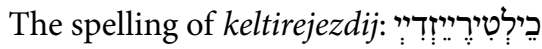

b. Da ündedi Avimeleh Avrahamny da ajtty anar ne qyldyj bizǵa da ne jazyqly boldum saja ki k el t $\boldsymbol{i}$ ŕ a j e $z \boldsymbol{d} \boldsymbol{i} \boldsymbol{j}$ üstüma da bijligim üstüńa ullu jazyq išlar ki qylynmajdylar qyldyj birgema. (TKow.01: $29 \mathrm{v}^{0}-30 \mathrm{r}^{\circ}$ )

\begin{tabular}{|c|c|c|c|c|c|}
\hline$D a$ & & Avimeleh & Avraham-ny & $d a$ & ajt-ty \\
\hline and & [3SG] & Abimelech-NOM & Abraham-Acc & and & say-PST-[3SG] \\
\hline 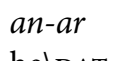 & & $q y l-d y-j$ & $b i z-g ́ a$ & & jazyqly \\
\hline AT & what & do-PST-2SG & we-DAT and & what & sinful \\
\hline
\end{tabular}

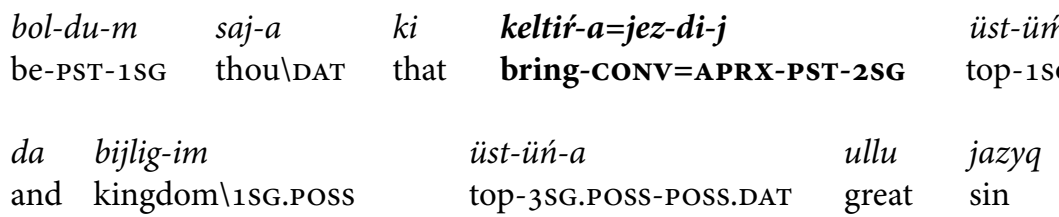

$\begin{array}{llll}i \text { š-lar } & k i & q y l y n-m a-j-d y l a r & q y l-d y-j \\ \text { matter-PL } & \text { which } & \text { be.done-NEG-PRS-3PL } & \text { do-PST-2SG }\end{array}$

birge-ḿ-a.

with-1SG.POSS-POSS.DAT

'And Abimelech called Abraham, and said to him, "What have you done to us? And how did I sin against you, that you have almost brought a great sin on me and on my kingdom? You have done things with me that are not done."

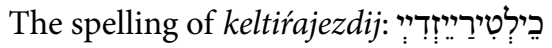

c. Da ind́adi Avimeleh Avrahamny da ajtty anar ne qyldyj bizǵa da ne jazyḥly boldum saja ki k e l t i ŕ a j e zd i jüstüma da bijligim üstüńa ullu jazyh išlar ki qylynmadylar qyldyj birǵama (Mickiewicz \& Rojecki 1889: 23).

$\begin{array}{lllll}\mathrm{Da} \text { inda-di } & \text { Avimeleh } & \text { Avraham-ny } & d a & \text { ajt-ty } \\ \text { and } & \text { call-PST-[3SG] } & \text { Abimelech } & \text { Abraham-ACC } & \text { and } \\ \text { say-PST-[3sG] }\end{array}$

9 Instead of the expected ündadi; it is perhaps a result of a blend with SWKar. indedi, which, in turn, might suggest that Mickiewicz and Rojecki (1889) also used South-Western Karaim sources in their editorial work. 


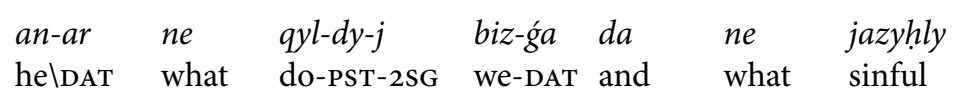

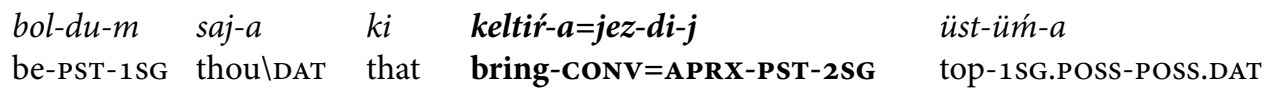

$\begin{array}{lllll}d a & \text { bijlig-im } & \text { üst- ̈ǘ- } a & \text { ullu } & \text { jazyh } \\ \text { and } & \text { kingdom\1sG.Poss } & \text { top-3sG.Poss-Poss.DAT } & \text { great } & \text { sin }\end{array}$

iš-lar $\quad$ ki $\quad$ qylyn-ma-dy-lar $\quad$ qyl-dy-j

matter-PL which be.done-NEG-PST-3PL do-PST-2SG

birǵa-ḿn-a.

with-1SG.POSS-POSS.DAT

'And Abimelech called Abraham, and said to him, "What have you done to us? And how did I sin against you, that you have almost brought a great sin on me and on my kingdom? You have done things with me that were not done."'

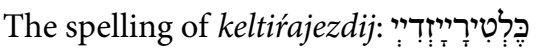

(2) jatajezdi and keltirejezdij (Genesis 26:10)

a. Da ajtty Avimeleh ne bu qyldyj bizǵa azǵgnaq $\mathbf{j}$ a t a $\mathbf{j} \boldsymbol{e} z \boldsymbol{d} \boldsymbol{i}$ birisi ol ulusnun qatynyjbyla da keltirgejdij üstümüzǵa fašmanlyq. (ADub.III.73: 39 ro)

Da ajt-ty Avimeleh ne bu qyl-dy-j

and say-PST-[3SG] Abimelech what this do-PST-2SG

biz-ǵa azg்naq jat-a=jez-di biri-si ol

we-DAT almost lie-CONV=APRX-PST-[3sG] one.of-3SG.POss-NOM ART

$\begin{array}{llll}\text { ulus-nun } & \text { qatyn-yj=byla } & d a \quad \text { keltir-gej-di-j } \\ \text { people-GEN } & \text { wife-2SG.POSs=with } & \text { and } & \text { bring-OPT-PST-2SG }\end{array}$

üst-ümüz-ǵa fašmanlyq.

top-1PL.POSS-DAT guilt

'And Abimelech said, "What is this you have done to us? One of the people has almost lain with your wife, and you would have brought guilt on us."

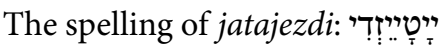


b. Da ajtty Avimeleh ne bu qyldyj bizge azg்ynaq $\mathbf{j}$ a $\mathbf{t}$ a $\mathbf{j}$ e $z \boldsymbol{d} \boldsymbol{i}$ birisi ol ulusnun qatynyjbyla da k elt ir e jezd $\boldsymbol{i j}$ üstümüzge fašmanlyq. (TKow.01: $40 \mathrm{v}^{0}-41 \mathrm{r}^{\mathrm{o}}$ )

$\begin{array}{llllll}\text { Da } & \text { ajt-ty } & \text { Avimeleh } & n e & b u & q y l-d y-j \\ \text { and } & \text { say-PST-[3sG] } & \text { Abimelech } & \text { what this } & \text { do-PST-2SG }\end{array}$

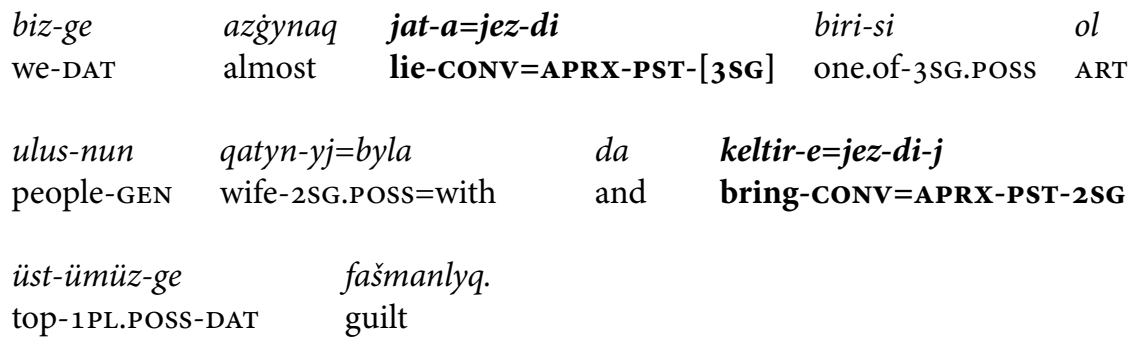

'And Abimelech said, "What is this you have done to us? One of the people has almost lain with your wife, and you have almost brought guilt on us."

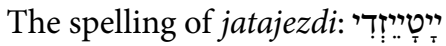

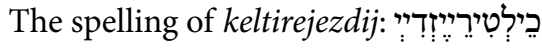

c. Da ajtty Avimeleh ne bu qyldyj bizǵa azg்yna ja taje $\boldsymbol{z} \boldsymbol{d} \boldsymbol{i}$ birisi ol ulusnun qatynyjbyla da keltirgejdij üstümüzǵa fašmanlyq. (Mickiewicz \& Rojecki 1889: 31)

$\begin{array}{llllll}\text { Da } & \text { ajt-ty } & \text { Avimeleh } & n e & b u & q y l-d y-j \\ \text { and } & \text { say-PST-[3sG] } & \text { Abimelech } & \text { what this } & \text { do-PST-2SG }\end{array}$

$\begin{array}{lllll}\begin{array}{l}\text { biz-ǵa } \\ \text { we-DAT }\end{array} & \begin{array}{l}\text { azǵyna } \\ \text { almost }\end{array} & \begin{array}{l}\text { jat-a=jez-di } \\ \text { lie-CONV=APRX-PST-[3SG] }\end{array} & \begin{array}{l}\text { biri-si } \\ \text { one.of-3SG.POSs }\end{array} & \begin{array}{l}\text { ol } \\ \text { ART }\end{array} \\ \text { ulus-nun } & \text { qatyn-yj=byla } & \text { da } & \text { keltir-gej-di-j } & \\ \text { people-GEN } & \text { wife-2SG.POSs=with } & \text { and } & \text { bring-OPT-PST-2SG }\end{array}$

$\begin{array}{ll}\text { üst-ümüz-ǵa } & \text { jazyh. } \\ \text { top-1PL.POSs-DAT } & \text { sin }\end{array}$

'And Abimelech said, "What is this you have done to us? One of the people has almost lain with your wife, and you would have brought sin on us."

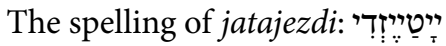


d. Da ajtty Avimeleh ne bu qyldyn bizge azg்naq $\mathbf{j}$ a ta $\mathbf{j}$ e $\boldsymbol{z} \boldsymbol{d} \boldsymbol{i}$ birisi ol ulusnun qatynyn byla da keltirgijdin biznin istine fasmanlyq jazyq. (JSul.III.01: $27 \mathrm{r}^{\circ}$ )

$\begin{array}{llllll}\mathrm{Da} & \text { ajt-ty } & \text { Avimeleh } & n e & b u & q y l-d y-n \\ \text { and } & \text { say-PST-[3SG] } & \text { Abimelech } & \text { what this } & \text { do-PST-2SG }\end{array}$

$\begin{array}{lllll}\text { biz-ge } & \text { azg்naq } & \text { jat-a=jez-di } & \text { biri-si } & \text { ol } \\ \text { we-DAT } & \text { almost } & \text { lie-CONV=APRX-PST-[3SG] } & \text { one.of-3sG.POSS } & \text { ART }\end{array}$

$\begin{array}{lllll}\text { ulus-nun } & \text { qatyn-yn } & \text { byla } & d a & \text { keltir-gij-di- } n \\ \text { people-GEN } & \text { wife-2SG.POSs } & \text { with } & \text { and } & \text { bring-OPT-PST-2SG }\end{array}$

$\begin{array}{llll}\text { biz-nin } & \text { ist-in-e } & \text { fašmanlyq } & \text { jazyq. } \\ \text { we-GEN } & \text { top-3SG.POSS-POSs.DAT } & \text { guilt } & \sin \end{array}$

'And Abimelech said, "What is this you have done to us? One of the people has almost lain with your wife, and you would have brought guilt sin on us."”

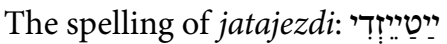

(3) ölaeźdim

B́ut’uń kuń... butúuń kuń... öla-eźdim kajġydan... (Kowalski 1929: 117)

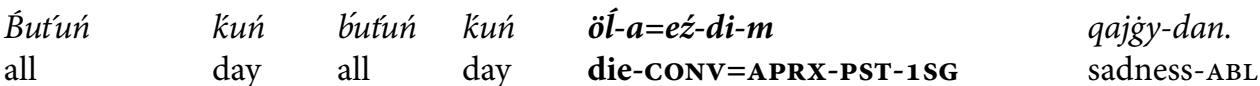

For the entire day... for the entire day... I almost died of sadness.

Spelled: «öla-eźdim〉

(4) ölaeźdim, baraeźdim, śozlaeźdim

a. $\ddot{o} \hat{l}-a=e z-d i-m$

die - CONV $=$ APRX - PST -1 SG

'I almost died'

Spelled: «öla-ez-dim〉 


\section{b. $b a r-a=e z-d i-m$}

go-CONV=APRX-PST-1SG

'I almost went'

Spelled: 〈bara-ez-dim〉

c. śozla $=e z-d i-m$ [sic!]

speak=APRX-PST-1SG

'I almost spoke'

Spelled: «siozla-ez-dim`

\section{MORPHOLOGICAL AND MORPHONOLOGICAL ANALYSIS}

Let us start with examinig the fact that the vowel of the auxiliary verb underwent a fronting process, i.e., an $a>e$ shift took place in MWKar. ${ }^{\star} j a z$ - $>$ MWKar. jez-. Although the ja- $>$ je-change is not unprecedented either in Karaim dialects or in Turkic languages in general (see e.g. Räsänen 1949: 81; von Gabain 1959: 51), it is not commonplace in Western Karaim. Seen in this light, it requires commentary and an explanation.

In Turkic languages, the fronting of $a$ is often caused by adjacent $j, \check{z}, \check{s}$, or $\check{c}$ - regardless of whether the consonants above follow or precede $a$, see, e.g. Bshk. jäš 1 . young; 2 . year of age' - the reflex of Tkc. jāš' 1. moist; fresh (of vegetation); 2. young, Bshk., EKar., Tat., etc. äjt- id. - the continuant of Tkc. ajt- 'to say', Bshk., Tat. bäjlä- 'to tie' - the reflex of Tkc. bagla- (see Räsänen [1969], Sevortjan [1974], Ščerbak [1970: 38], Tenišev [1984: 144]), or Kipch. CC alaj alej 'thus; this way' (Radloff 1887: 5, s.v. arai).

As far as the Karaim data is concerned, the eastern (Crimean) dialect provides further examples of the ja- > jä- change, see the reflexes of Tkc. jāš 'young', namely, EKar. jaš jäš '1. young; 2. green' vs. NWKar. jaš' 1 . young; 2. year of age', SWKar. jas id., or the Karaim cognates of Tkc. janč'to crush', namely, EKar. janč- jenč- 'to strike; to crush, to destroy' vs. NWKar. janč- id., SWKar. janc-id., to mention only a few (the data is excerpted from KarRPS, and Aqtay and Jankowski [2015]). In fact, in Eastern Karaim, the $a j>a ̈ j, a \check{c}>\ddot{a} \check{c}$, and $a \check{z}>\ddot{a} z ̌$ processes were quite frequent, too, ajtalar > äjtälär 'they say', sač > säč 'hair', and ažyjym > äžijim 'I am sorry' (KarRPS 500; Prik 1976: 41; Jankowski 2003: 122) being good examples here.

The comparative data for the ja- > je-change in Western Karaim is, however, quite modest. Zajączkowski (1932: 152-153) took this change into account and added it to the list of sound changes that occurred in Western Karaim stems and suffixes (Zajączkowski 1932: 152-163) and provided three instances of it in the following words:

- ješil'green' < ${ }^{*} j a s ̌ y l$,

- jerǵa 'grade, layer' < jarǵa, and

- jeld'a- 'to delude' < ‘jalda- < alda- 'to delude; to lie; to cheat'. 
The etymology of the third example holds water and, in light of WKar. alda- 'to delude; to lie; to cheat', serves as a good analogy for Kar. ${ }^{*} j a z->$ jez- even if must assume the development of a prothetic $j$ - in jeld $\hat{a}^{-}$-, which prothetic sound is, parenthetically saying, also attested in the Mamluk Kipchak jalda- 'to mislead, to deceive' (see Tekin 1994: 56). Given that all the Turkic cognates of this widespread verb have back vocalism and the emergence prothetic $j$ - sound is rare (ESTja 1974: 127), we can safely say that both the appearance of the prothetic sound and the ja > je change are not inherited phenomena, but they occurred in Karaim.

The ${ }^{\star} j a>j e$ shift in ješil 'green' raises no doubts, either; the same phenomenon took place in a number of its Turkic cognates (ĖSTJa 1974: 164-165) and, hence, there is no reason to question its occurrence in Karaim.

However, jerǵa 'grade, layer' does not appear to be a perfect parallel here. Zajączkowski (1932: 153) etymologizes jerǵa as a - $\dot{g} a$ derivative of jar- 'to crack, to break', but the word's origin is far from being clarified. What definitely undermines Zajączkowski's view is that all Turkic cognates exhibit front vocalism (including Yakut). In other words, there is no trace of $j a$ - on the onset in its Turkic equivalents, see Räsänen (1969: 198), Radlov (1905: III/1: 341). ${ }^{10}$

We can, therefore, say that there are at least (or only) two analogous examples for the ja- > $j e$ - change in Western Karaim. It is important to note that the well-known NWKar. aj $>$ ej change should not be referred to here as an analogous process, since it operated at a much later date and in a different phonotactic environment; more precisely: the latter process was documented for $19^{\text {th }}$-century Modern North-Western Karaim (Németh 2015b: 174-175; 2018b: 155) and took place only when $j$ was in the syllable-closing position.

Besides the development of the analysed ${ }^{*} j a z-$, there is no other trace of the $j a>j e$ change in ADub.III.73. Neither did we manage to find more relevant examples in any of the manuscripts we have been fortunate to deal with so far, let alone in the available scholarly works. Nevertheless, the orthography of all the examples presented above leaves no doubt that the vowel fronting in this auxiliary did indeed take place. The comparative material gives us grounds for assuming that the change could have been phonetically motivated, but in light of the scant number of parallel examples the question needs to be asked why the shift occurred with this verb? To have a better understanding of this problem, we should take note of the fact that by the time these examples were recorded the verb ${ }^{*}$ jaz- (jez-) had (most probably) lost its original lexical meaning and had already been grammaticalized. ${ }^{11}$ The change in the stem vowel, therefore, may have been the result of (or occurred in parallel with) the reduction in the informational load of the verb, which is often the case when a lexeme is grammaticalized (see e.g., Dahl 2011: 158). The change could additionally have been catalysed by the need to avoid homonymy with the verb jaz- 'to write'.

Having said this, we have grounds to believe that the ${ }^{*} j a z->$ jez-change took place in Western Karaim as a result of an assimilative phonetic process possibly reinforced by semantic phenomena.

However, there are further matters to be explained in relation to the other examples. As is shown in the table below, in examples (3), and (4a-b) the auxiliary lacks the word-initial $j$-,

10 Räsänen (1969: 198) proposed a Mongolic etymology which, regardless of its value, has the advantage over Zajączkowski's idea of not involving the reconstruction of the ${ }^{*} j a>$ je change. Radlov's (1905: III/1: 341) idea to explain jerǵa as the dative case form of jer 'place' might raise certain doubts, too.

11 ĖSTJa (1989: 72-73, s.v. ŭa:3-) provides a list of Turkic languages in which the verb jaz- 'to miss; etc.' is (or, was, cf. the historic idioms of Turkic) used. The cognates of Tkc. $\bar{a} z$ - 'to get lost; to lost one's way', including Kar. $a z$ - ' 1 . to err; to get lost; to lose one's way; 2. to prostitute, to fall into harlotry' (KarRPS 1974: 47) are collected in ĖSTa (1974:

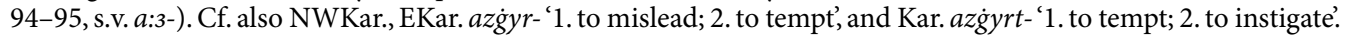


whereas in example (3c) both the word-initial $j$ - and the converbial $-j$ are missing. To put it more concisely, we would expect the following forms:

Table 1. Examples (3), (4a), (4b), (4c) and their expected equivalents

\begin{tabular}{l||l|l} 
Example & There is & Expected forms \\
\hline 3 & ölaezdim & ${ }^{\star}$ ölajezdim \\
\hline $4 \mathrm{a}$ & ölaezdim & ${ }^{\star}$ ölajezdim \\
\hline $4 \mathrm{~b}$ & baraezdim & ${ }^{\star}$ barajezdim \\
\hline $4 \mathrm{c}$ & śozĺaezdim & ${ }^{\star s ́ z o ́ l a j j e z d i m ~}$
\end{tabular}

There is no analogy in Turkic languages either for the loss of the word-initial $j$-, or for forms with front vocalism in the equivalents of the auxiliary jaz- (ESTJa 1989: 72-73). The only front vocalic form we found in the scholarly literature is Tat. $\ddot{z} z$ - 'to get lost' listed by Räsänen (1969: 33, s.v. $\bar{a} z$ ), but we could not confirm its existence in other sources (TatRussS 1966; TTDS 1969; TatRussS 2004), and, secondly, it is a reflex of the above-mentioned Tkc. verb $\bar{a} z$ - which, although etymologically (most likely) related to Tkc. jāz-, never played the role of an auxiliary verb. Neither can the above-mentioned NWKar. $e z$ - be identified with Kar. $a z$ - 'to err; etc., because the fronted vocalism can only be explained through the influence of the adjacent $j-$.

It is not entirely clear what the reason was for the loss of this word-initial $j$-. One explanation that could be theoretically considered here is the analogy with Kar. az- ' 1 . to err; to get lost; to lose one's way; 2 . to prostitute oneself, to fall into harlotry', but this can be valid only if we assume that the speakers were able to consult their own feel for the language and identify the semantic (or etymological) connection between the auxiliary jez-forming verbs meaning to almost do something' and a verb meaning ' 1 . to err; to get lost; to lose one's way; 2 . to prostitute oneself, to fall into harlotry' - which cannot be either confirmed or rejected. Additionally, the difference in vocalism would also remain undetermined in this case.

A much better interpretation would be to assume that the process of grammaticalization of jez- eventually led to irregularities in the paradigm as the borderline between morphemes became obscured and, as a result, the word-initial $j$ - was reinterpreted as a non-etymological sound like the one used in the Western Karaim abilitive mood construction $-a l \sim-j$-al to avoid hiatus: $-j$ - is added to the abilitive mood marker -al- (etymologically speaking, a cognate of al- 'to take', primarily an auxiliary verb which eventually evolved into the WKar. $(j) a l-\sim(j) e l$ suffix) when it follows a verbal stem ending in a vowel (Zajączkowski 1932: 126-127).

Finally, the form śozlaezdim (example 4c), which also lacks the converbial $-j$, is most likely an erroneously adduced form, in which the stem-ending - $a$ of śźla- 'to speak' was mistakenly identified as the $-a$ converb. As we see in examples (4a) and (4b), in turn, the converbial $-a$ is correctly used.

\section{FINAL THOUGHTS. SEMANTIC AND CHRONOLOGICAL ANALYSIS}

Biblical translations have one significant advantage: the context of each grammatical form can be specified very precisely. Below, we have summarized the Biblical context of verses Genesis 20:9 and 26:10: 
(1) keltirejezdij 'you have almost brought': After Abraham had arrived in Gerar, he lied that Sarah was not his wife but rather was his sister and hence she was taken to the harem of Abimelech, King of Gerar. Abimelech learned the truth in a dream through divine communication and he was warned that he would die if he does not give back Sarah to Abraham. Abimelech, therefore, sent Sarah back and said to Abraham that he has almost caused him and his nation to commit a mortal sin. (Genesis 20:1-9)

(2) jatajezdi 'has almost lain' and keltirejezdij 'you have almost brought': Like his father Abraham, famine forced Isaac to go to Gerar, whose king was Abimelech, styled 'King of the Philistines. To save his life, Isaac passed off his wife, Rebekah, as his sister, until Abimelech surprised them in their connubialities and learned that she is his wife. The king rebuked Abraham for not saying the truth and said that his people have almost incurred the guilt of unconscious adultery through his lie. (Genesis 26:1-10)

As far as the other examples are concerned, the context in which ölaeźdim is used in Firkowicz's play leaves no doubt that it expresses an action that nearly happened: it comes from a dialogue of a couple in love, see Kowalski (1929: 117). Kowalski includes the auxiliary $e z$ - in a separate entry in the glossary and explains it as: 'entstanden aus ursprünglichen iaz' (Kowalski 1929: 186, s.v. $\left.e z^{-\mathrm{II}}\right)$ and he translated the form ölaezdim as 'beinahe wäre ich gestorben.' ${ }^{12}$

On the other hand, the three examples described by J. Sulimowicz were supplemented with a concise single-word explanation in the form of the Polish expression ledwom 'I barely', which is not the most accurate translation of this construction if we bear in mind the difference between 'I almost died' and 'I barely survived'.

The material we collected, though modest, shows that in Western Karaim the analysed construction did not lose the role it was known to perform in other Turkic languages, namely to denote unintended actions (which eventually did not take place). Moreover, the evidence provided by the comparative Turkic data allows us to assume that the Western Karaim approximative was most likely used in the present and past tense, only, and it was not attached to negative verbs.

The lack of a back-harmonic variant of jez- ez-and, to certain extent, also the way in which example (3) was published in Kowalski (1929: 117; i.e. ‘öla-eźdim〉 with a hyphen between the converbial stem and the approximative marker) suggest that the morpheme in question was treated not as a suffix, but rather as an auxiliary verb deep into the $20^{\text {th }}$ century.

It is worth to note that in the Eastern Karaim translations of the Torah to which we have been fortunate to gain access, the simple past, imperfect, and past conditional forms are used (also in adverbial constructions) where approximative forms exist in the verses quoted above, see ketirdin 'you brought' (simple past, $2^{\text {nd }}$ sg.; Genesis 20:9; BSMS 288: 23 vo; Gaster Hebrew 170: $9 \mathrm{r}^{\mathrm{o}}$ ), azdan jatyr edi 'almost lied' (imperfect, $3^{\text {rd }}$ sg.; Genesis 26:10; BSMS 288: $29 \mathrm{v}^{\circ}$ ), azdan jatsa edi 'almost lied' (past conditional, $3^{\text {rd }}$ sg.; Genesis 26:10; Gaster Hebrew 170: 19 ro ), ketirir ediy 'you brought'

\footnotetext{
12 The same example is adduced by Zajączkowski (1932: 65) in a paragraph describing the deverbal nominal suffix $-(y) q$ : among numerous other examples, he mentions Kar. jazyq 'sin' which is ultimately a derivative of Tkc. jaz- 'to

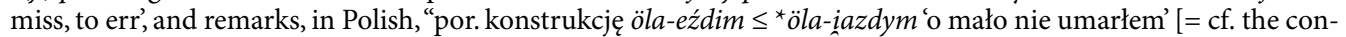
struction öla-eźdim $\leq{ }^{\star} \ddot{o l a}$-ịazdym 'I almost died']. Given that in his introduction Zajączkowski (1932: 6) clearly states that his work is based on the lexical material collected by Kowalski (1929), there is no doubt that Zajączkowski's example is also, in this case, taken from there. Finally, it is worth noting that Zajączkowski (1932: 65) adduces Kar. ${ }^{*} j a z$ - as an asterisked form, which means that, in his view, ${ }^{*} j a z$ - did not exist either in the spoken language in his lifetime, or in the written sources he was acquainted with.
} 
(imperfect; $2^{\text {nd }}$ sg.; Genesis 26:10; BSMS 288: 29 v ), and getirir edin (imperfect; $2^{\text {nd }}$ sg.; Genesis 26:10; Tiriškan 1841: $23 \mathrm{r}^{\circ}$ ). Additionally, in the Eupatorian edition of the Tanakh published by Tiriškan (1841), futurum II forms are also employed - in combination with the past tense form of the $e$ - 'to be' copula verb. The use of the latter construction is clear evidence of Oghuzic influence - in Crimean Karaim, this compound tense was employed to express a past-tense action that its performer intended to do or was obliged to do (Prik 1976: 142), see getirežek edin 'you intended to bring' (Genesis 20:9; Tiriškan 1841: I: $16 \mathrm{v}^{\circ}$ ), and jatažaq edi ' [he] intended to lie' (Genesis 20:9; Tiriškan 1841: I: $22 \mathrm{v}^{\circ}$ ).

Finally, we should also pose the question when this category eventually ceased to function in Western Karaim. Quite telling is the fact that all authors of grammatical descriptions of this language left this construction undiscussed. In case of non-Karaim authors this might have been a corollary of the absence of a representative number of Karaim written sources available. But this list of authors includes also Ananjasz Zajączkowski (1903-1970) and Mykolas Firkovičius (19242000), who were native speakers of Karaim, see Zajączkowski (1931), Firkovičius (1996). The latter fact and the mistakenly quoted and inaccurately interpreted data of Józef Sulimowicz - after all, a Turcologist and native-speaker of South-Western Karaim, too - might suggest that the Western Karaim approximative was no longer a productive (or, at least, a commonly used) category in the idiolects of speakers born at the beginning of the $20^{\text {th }}$ century. Moreover, it should also be emphasized that in the case of the $20^{\text {th }}$-century examples only highly educated native speakers of Western Karaim confirmed philologically its existence. So it is likely that this category ceased to be productive in spoken Karaim somewhat earlier than the turn of the $20^{\text {th }}$ century.

\section{ACKNOWLEDGEMENTS}

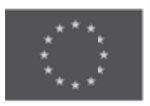

erc

The research upon which this publication is based has been awarded funding from the European Research Council (ERC) under the European Union's Horizon 2020 research and innovation programme (grant agreement no. 802645). The task of preparing the transcription and the English translation of manuscript ADub.III.73 as well as that of collecting the required linguistic data was financed by the National Science Centre of Poland (Pol. Narodowe Centrum Nauki; research project agreement no. 2015/17/B/HS2/01498).

\section{EDITORIAL SYMBOLS}

\begin{tabular}{ll}
\hline$a b c>c b a$ & borrowing, internal development \\
$a b c \rightarrow c b a$ & derivation \\
${ }^{\star} a b c$ & reconstructed or not attested form \\
$\langle\mathrm{abc}>$ & orthographic notation \\
$a b c \sim c b a$ & alternation
\end{tabular}




\section{ABBREVIATIONS}

$\mathbf{A B L}=$ ablative $\mid \mathbf{A C C}=$ accusative $\mid$ Alt. $=$ Altay $\mid \mathbf{A P R X}=$ approximative $\mid$ arch. $=$ archaic. $\mid \mathbf{A R T}=$ article $\mid$ Bshk. $=$ Bashkir $\mid$ CTat. $=$ Crimean Tatar $\mid \mathbf{C V B}=-a$ converb $\mid \mathbf{D A T}=$ dative $\mid$ EKar. $=$ Eastern (Crimean) Karaim $\mid$ Eng. = English $\mid$ GEN $=$ genitive $\mid$ Germ. $=$ German $\mid$ INDEF $=$ indefinite $\mid$ Kar. $=$ Karaim $\mid$ Kipch. $\mathbf{C C}=$ the language of Codex Comanicus $\mid$ Kirg. = Kirghiz $\mid$ Kklp. = Karakalpak $\mid$ Kzk. = Kazakh $\mid \mathbf{m s .}=$ manuscript $\mid$ MWKar. $=$ Middle Western Karaim $\mid$ NEG $=$ negative suffix $\mid$ Nog. $=$ Nogai $\mid$ NOM $=$ nominative $\mid$ NWKar. $=$ North-Western Karaim $\mid$ OPT $=$ optative $\mid \mathbf{P L}=$ plural $\mid$ Pol. $=$ Polish $\mid$ POss $=$ possessive $\mid \mathbf{P R S}=$ present $\mid$ PST $=$ simple $($ Tkc. $-d y)$ past $\mid$ PTkc. - Proto-Turkic $\mid \mathbf{s G}=$ singular $\mid$ SWKar. $=$ South-Western Karaim $\mid$ Tat. = (Kazan) Tatar $\mid$ Tkc. $=($ General) Turkic $\mid$ Tksh. $=$ Turkish $\mid$ Uyg. $=$ Uyghur $\mid$ Uzb. $=$ Uzbek $\mid$ WKar. $=$ Western Karaim

\section{REFERENCES}

\section{Primary sources}

ADub.III.73 = A translation of the Torah, the Book of Ruth, the Book of Jeremiah, Ecclesiastes, and the Book of Esther into North-Western Karaim. The Torah was copied between 25 Mar 1720 and 31 May 1720, the other books were copied after 31 May 1720 and before 27 Mar 1723, in Kukizów by Simcha ben Chananel (died 27 Mar 1723). Stored in Warsaw in the private archive of the late Aleksander Dubiński (1924-2002). 385 folios. Critically edited in Németh (2021).

BSMS 288 = A translation of the Tanakh (without 1-2 Chronicles) into Eastern Karaim. Copied in four volumes in the $18^{\text {th }}$ century. Volumes 1 and 4 (i.e., Pentateuch, The Song of Songs, Ruth, Lamentations, Ecclesiastes, Esther, Psalms, Proverbs, Job, Daniel, Ezra and Nehemiah) were critically edited in Jankowski et al. (2019). Stored in the Cambridge University Library. 620 folios.

Gaster Hebrew MS 170 = An Eastern Karaim translation of a large portion of the Torah (Genesis 1:1 Deuteronomy 32:51) and the Book of Lamentations (4:11-5:22). Copied in the beginning of the $19^{\text {th }}$ century. Stored in the John Rylands Library of The University of Manchester Library. Described by Jankowski (1997), its full text compared with BSMS 288 in Jankowski \& Aqtay \& Cegiołka \& Çulha \& Németh (2019). Full text available on-line at: https://luna.manchester.ac.uk/luna/servlet/s/a0jk2m (accessed 7 Apr 2020). 265 folios.

JSul.III.01 = A translation of the Torah and of some fragments of the books of Joshua, Judges, 1-2 Kings, Isaiah, Jeremiah, Ezekiel, Hosea, Joel, Obadiah, Micah, Habakkuk, and Zechariah (i.e., Torah and Haftarah) into South-Western Karaim. Copied by Jeshua Josef Mordkowicz (1802-1884) in Halych in the mid- $19^{\text {th }}$ century. Stored in Warsaw in the private archive of the late Józef Sulimowicz (1913-1973). 298 folios.

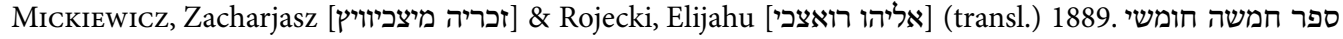
תורה מתורגם ללשון קדרי לבני מקרא קודש המורגלת בפי קהלות הקראים הדרים בגלילות רוסיא тора, т. е., Пятикнижие Ветхаго Завпта, переведенное на караимское нартиіе посредствомь Захарія Михайлова Мицкевича и Илья Исаева Роецкаго. Vilnius.

Sulimowicz (1969) = A notebook of Józef Sulimowicz (1913-1973) with notes in Polish on Karaim grammar and lexicography. Kept in the private archive of Józef Sulimowicz in Warsaw.

TirišKan, Mordechai [מרדכי טירישקן] (ed.) ספר תרגום תורה בלשון טטר . 1841 Sefer Targum Torah bi-lešon Țațar. Vol. 1-4. Gözleve [= Eupatoria]. 
TKow.01 = A translation of the Torah into North-Western Karaim. A partially vocalised manuscript mistakenly described by Kowalski (1929: 289) and Zajączkowski (1939: 94) as a manuscript created in 1723 in Derażne. Copied in Kukizów by Simcha ben Chananel (the copyist of ADub.III.73). It was finished on 7 December 1722 A.D. Kept in the private archive of Józef Sulimowicz in Warsaw. 351 folios.

\section{Secondary sources}

AQtAY, Gülayhan 2009. Eliyahu ben Yosef Qılci's anthology of Crimean Karaim and Turkish literature. Critical edition with introduction, indexes and facsimile. Vol. 1-2. [Ylldız Dil ve Edebiyat Dizisi 8.] İstanbul: Mehmet Ölmez.

AqTAY, Gülayhan and Henryk Jankowski 2015. A Crimean Karaim-English dictionary. [Prace Karaimoznawcze 2.] Poznań: Katedra Studiów Azjatyckich.

Basкaкov, Nikolaj Aleksandrovič [Баскаков, Николай Александрович] 1947. Очерк грамматики ойротского языка. Москва: Издательство Академии наук СССР.

BasкAкov, Nikolaj Aleksandrovič [Баскаков, Николай Александрович] 1952. Каракалпакский язык. II. Фонетика и морфология. Часть 1. Части речи и словообразование. Москва: Издательство Академии наук СССР.

BAsкAкov, Nikolaj Aleksandrovič [Баскаков, Николай Александрович], Ananiasz ZAJĄCzкowsкi and Seraja Markovič ŠAPšAL [Шапшал, Серая Маркович] (ред.) 1974. Караимско-русско-польский словарь. Slownik karaimsko-rosyjsko-polski. Москва: Издательство «Русский язык».

Benson, Joseph 1857. The Old Testament and New Testament of our Lord and Saviour Jesus Christ. (According to the present authorized version.) With critical, explanatory, and practical notes: The marginal readings of the most approved printed copies of the New Testament with such others as appear to be countenanced by the original Greek: A copious collection of parallel texts; summaries of each book and chapter; and the date of every transaction and event recorded in this part of the sacred oracles, agreeably to the calculations of the most correct chronologers. Vol. 1. New York: T. Carlton \& J. Porter. [Available at https://biblehub.com/commentaries; without page numbers indicated; accessed 8 April 2020].

Berta, Árpád 1998. 'West Kipchak languages.' In: Lars Johanson and Éva Ágnes Csató (eds.) The Turkic Languages. London-New York: Routledge, 301-317.

Blagova, Galina Fedorovna [Благова, Галина Федоровна] 1994. «Бабур-наме». Язык, прагматика текста, стиль: к истории чагатайского литературного языка. Москва: Российская академия наук.

Bodrogligeti, András J. E. 2001. A grammar of Chagatay. [Languages of the World/Materials 155.] München: Lincom Europa.

CegroŁka, Dorota 2019. 'A South-Western Karaim Bible translation of the Book of Genesis in manuscript no. JSul.III.01'. Almanach Karaimski 8: 9-33.

Clauson, Sir Gerard 1972. An Etymological Dictionary of Pre-Thirteenth-Century Turkish. Oxford: Clarendon Press.

Csató, Éva Ágnes and Karakoç, Birsel 1998. 'Noghay’. In: Lars Johanson and Éva Ágnes Csató (eds.) The Turkic Languages. London-New York: Routledge, 333-343.

ÇulHa, Tülay 2006. Karaycanın Kısa Sözvarlığı. Karayca-Türkçe Kısa Sözlük. [Dil ve Edebiyat Dizisi 6.] İstanbul: Mehmet Ölmez.

DAHL, Östen 2011. 'Grammaticalization and linguistic complexity.' In: Bernd HeInE and Heiko NArrog (eds.) The Oxford Handbook of Grammaticalization. Oxford: Oxford University Press, 153-162.

Dankoff, Robert and James Kelly 1982-1985. Mahmmūd al-Käšğarī. Compendium of the Turkic dialects (Dīwān Lug̀āt at-Turk). Vol. 1-3 [vol. 1: 1982; vol. 2: 1984; vol. 3: 1985]. Duxbury: Harvard University Printing Office. 
Drimba, Vladimir 2000. Codex Comanicus. Édition diplomatique avec fac-similés. București: Editura Enciclopedică.

DTS = Nadeljaev, Nasilov, Tenišev and Ščerbak 1969.

Džanmavov, Jusup Džangišievič [Джанмавов, Юсуп Джангишиевич] 1967. Деепричастия в кумыıкком литературном языке. Москва: Издательство «Наука».

Eскмann, János 1966. Chagatay manual. [Indiana University Publications. Uralic and Altaic Series 60.] Bloomington: Indiana University and The Hague: Mouton and Co.

ERdal, Marcel 2004. A Grammar of Old Turkic. [Handbook of Oriental Studies. Section Eight: Central Asia 3.] Leiden-Boston: Brill.

ÈSTja (1974) $=$ Sevortjan 1974.

ÈSTja (1989) = Levitskaja 1989.

Firkovičıus, Mykolas 1996. Mień karajče ürianiam. Vilnius: Danielius.

Friedman, Richard Elliott 2003. The Bible with sources revealed. A new view into the Five Books of Moses. New York: HarperOne.

von Gabain, Annemarie 1959. 'Die Sprache des Codex Cumanicus.' In: Jean Deny, Kaare Grønbech, Helmuth Scheel and Zeki Velidi Togan (eds.) Philologiae Turcicae Fundamenta. Vol. 1. Wiesbaden: Franz Steiner, 46-73.

Ganiev, Fuat Ašrafovič [Ганиев Фуат Ашрафович] (ред.) 2004. Татарско-русский словарь. Татарча-русча сүзлек. Казань: Татарское книжное издательство.

Golovkina, O. V. [Головкина, О. В.] (ред.) 1966. Татарско-русский словарь. Москва: Издательство «Советская энциклопедия».

Gülsevin, Selma 2016. Karay Türklerinin Dili (Troki Diyalekti). [Türk Dil Kurumu Yayınları 1165.] Ankara: Türk Dil Kurumu.

Hebert, Raymond J. and Nicholas Poppe 1963. Kirghiz Manual. [Indiana University Publications. Uralic and Altaic Series 33.] Bloomington: Curzon.

JAnkowski, Henryk 1992. Gramatyka języka krymskotatarskiego. Poznań: Wydawnictwo Naukowe UAM.

Jankowski, Henryk 1997. 'A Bible translation into the northern Crimean dialect of Karaim.' Studia Orientalia 82: 1-82.

Jankowski, Henryk 2003. 'On the Language Varieties of Karaims in the Crimea.' Studia Orientalia 95: 109130.

JANKowski, Henryk 2010. Język krymskotatarski. Warszawa: Dialog.

Jankowski, Henryk 2014. 'Two Karaim religious poems by Isaac ben Abraham Troki.' Karaite Archives 2: $35-57$.

Jankowski, Henryk, Gülayhan Aqtay, Dorota CegioŁka, Tülay Çulha and Michał Németh 2019. The Crimean Bible. Vol. 1. Critical edition of the Pentateuch, Five Scrolls, Psalms, Proverbs, Ezra and Nehemiah. Vol. 2. Translation. [Turcologica 119.] Wiesbaden: Harrassowitz.

JoHANSON, Lars 1999. 'Typological notes on aspect and actionality in Kipchak Turkic.' In: Abraham Werner \& Leonid Kulikov (eds.) Tense-aspect, transitivity and causativity. Essays in honour of Vladimir Nedjalkov. [Studies in Language Companion Series 50.] Amsterdam-Philadelphia: John Benjamins, 171-184.

Judachin, Konstantin Kuźmič [Юдахин Константин Кузьмич] 1965. Киргизско-русский словарь. Кыргызча-орусча сөздүк. Vol. 1-2. Москва: Издательство «Советская энциклопедия».

JuldašEv, Achnef Achmetovič [Юлдашев, Ахнеф Ахметович] 1965. Аналитические формы глагола в тюркских языках. Москва: Издательство «Наука».

JuldAšEv, Achnef Achmetovič [Юлдашев, Ахнеф Ахметович] 1981. Грамматика современного бамкирского литературного языка. Москва: Издательство «Наука». 
KarRPS = Baskakov, Zajączkowski and Šapšal 1974.

Kerslake, Celia 1998. 'Ottoman Turkish.' In: Lars Johanson and Éva Ágnes Csató (eds.) The Turkic Languages. London-New York: Routledge, 179-202.

KirgRussS = Judachin 1965 .

Kononov, Andrej Nikolaevič [Кононов андрей Николаевич] 1956. Грамматика современного турецикго языка. Москва-Ленинград: Издательство Академии наук СССР.

Kowalski, Tadeusz 1929. Karaimische Texte im Dialekt von Troki. [Prace Komisji Orjentalistycznej Polskiej Akademji Umiejętności 11.] Kraków: Polska Akademia Umiejętności.

Kuun, Géza 1880. Codex Cumanicus. Bibliothecae ad templum divi Marci Venetiarum. Budapest: Editio Scient. Academiæ Hung.

LevitskajA, Lija Sergeevna [Левитская, Лия Сергеевна] (ред.) 1989. Этимологический словарь тюркских языков. Общетюркские и межтюркские основы на буквы "Ж”, "Ж”, "Й”. Москва: Издательство «Наука».

Mаснмuтоva, Lejla Tagirovna [Махмутова, Лейла Тагировна] (ред.) 1969. Диалектологический словарь татарского языка. Татар теленең диалектологик сүзлеге. Казань: Татарское книжное издательство.

Munamedowa, Raihan 2016. Kazakh. A Comprehensive Grammar. Abingdon, New York: Routlege.

Musaev, Kenesbaj Musaevič [Мусаев, Кенесбай Мусаевич] 1964. Грамматика караимского языка. Фонетика и морфология. Москва: Издательство «Наука».

Musaev, Kenesbaj Musaevič [Мусаев, Кенесбай Мусаевич] 1977. Краткий грамматический очерк караимского языка. Москва: Издательство «Наука».

Nadeljaev, Vladimir Michajlovič [Наделяев Владимир Михайлович], Dmitrij Michajlovič NAsılov [Дмитрий Михайлович Насилов], Edchjam Rachimovič Tenišev [Эдхям Рахимович Тенишев] and Aleksandr Michajlovič Šč́rвак [Александр Михайлович Щербак] (ред.) 1969. Древнетюркский словарь. Ленинград: Издательство «Наука». Ленинградское отделение.

NADžıp, Emir Nadžipovič [Наджип, Эмир Наджипович] 1960. Современныцй уйгурский язык. Москва: Издательство восточной литературы.

NÉMETH, Michał 2011a. Unknown Lutsk Karaim letters in Hebrew script $\left(19^{\text {th }}-20^{\text {th }}\right.$ centuries). A critical edition. [Studia Turcologica Cracoviensia 12.] Kraków: Wydawnictwo Uniwersytetu Jagiellońskiego.

NÉMETH, Michał 2011b. Zwięzła gramatyka języka zachodniokaraimskiego z ćwiczeniami. [Prace Karaimoznawcze 1.] Poznań: Katedra Studiów Azjatyckich.

NÉmETH, Michał 2013. Ananiasz Zajączkowski’s doctoral thesis. The original manuscript of Sufiksy imienne $i$ czasownikowe w język zachodniokaraimskim. Folia Orientalia 50: 115-157.

NÉmEth, Michał 2014. 'An early North-Western Karaim Bible translation from 1720. Part 1. The Torah.' Karaite Archives 2: 109-141.

NÉmeth, Michał 2015a. 'A historical morphology of Western Karaim. The - $p$ edi past tense in the southwestern dialect.' AOH 68/2: 215-228.

NÉMETh, Michał 2015b. 'A historical phonology of Western Karaim. The process of its diversification into dialects.' Studia Linguistica Universitatis Iagiellonicae Cracoviensis 132: 167-185.

NÉmeth, Michał 2015c. An early North-Western Karaim Bible translation from 1720. Part 2. The Book of Ruth.' Karaite Archives 3: 49-102.

NÉMETH, Michał 2016. A Crimean Karaim handwritten translation of the Book of Ruth dating from before 1687. Another contribution to the history of Crimean Karaim and to the question of the stemma codicum of the Eupatorian printed edition of the Tanakh from 1841.' Türk Dilleri Araștırmaları 26: 161-217. 
NÉMETH, Michał 2018a. 'An early North-Western Karaim text dating from before 1700. A linguist's contribution to the biography of Josef ha-Mashbir.' Almanach Karaimski 7: 83-98.

Németh, Michał 2018b. 'A historical phonology of Western Karaim. The process of its diversification into dialects. Part 2. Supplementary data on the absolute and relative chronology of sound changes.' Rocznik Orientalistyczny 71/2: 146-161.

NÉMETH, Michał 2019. 'A historical morphology of Western Karaim. The -a-d-continuative in the northwestern dialect.' International Journal of Eurasian Linguistics 1/2: 268-308.

NéMETh, Michał 2020. Middle Western Karaim. A critical edition and linguistic analysis of pre-18 $8^{\text {th }}$-century Karaim interpretations of Hebrew piyyutim. [The Languages of Asia 20.] Leiden-Boston: Brill.

NÉMETH, Michał 2021. The Western Karaim Torah. A critical edition of a manuscript from 1720. Vol. 1-2. [The Languages of Asia 24.] Leiden-Boston: Brill.

Olach, Zsuzsanna 2013. A Halich Karaim translation of Hebrew biblical texts. [Turcologica 98.] Wiesbaden: Harrassowitz.

Peake, Arthur S. (with the assistance of Grieve, Alexander James) (eds.) 1920. A Commentary on the Bible. New York: Thomas Nelson \& Sons, London: T. C. \& E. C. Jack.

Priк, OÍga Jakovlevna [Прик, Ольга Яковлевна] 1976. Очерк грамматики караимского языка (крымский диалект). Махачкала: Дагестанское государственное издательство учебно-педагогической литературы.

Pritsak, Omeljan 1959. 'Das Karaimische.' In: Jean Deny, Kaare Grønbech, Helmuth Scheel, Zeki Velidi Togan (eds.) Philologiae Turcicae Fundamenta. Vol. 1. Wiesbaden: Franz Steiner, 318-340.

Rachmatullin, Gabdul-Rashid 1928. 'Die Hilfsverben und Verbaladverbien im Altaischen. Ungarische Jahrbücher 8/1-2: 1-24, 309-343.

Radloff, Wilhelm 1887. Das türkische Sprachmaterial des Codex Comanicus. Manuscript der Bibliothek der Marcus-Kirche in Venedig. Nach der Ausgabe des Grafen Kuun (Budapest 1880). St.-Pétersbourg: Imperatorska Akademija Nauk.

Radlov, Vasilij Vasilevič [Радлов, Василий Васильевич] 1893-1911. Опыт словаря тюркских наргчий. Versuch eines Wörterbuches der Türk-Dialecte. Vol. 1-4 [vol. 1/1-2: 1893; vol. 2/1-2: 1899; vol. 3/1-2: 1905; vol. 4/1-2: 1911]. Санктпетербургъ: Императорска академия наукъ.

RäsÄNEN, Martti 1949. Zur Lautgeschichte der türkischen Sprachen. [Studia Orientalia 15.] Helsinki: Societas Orientalis Fennica.

RäsÄNEN, Martti 1957. Materialien zur Morphologie der türkischen Sprachen. [Studia Orientalia 21.] Helsinki: Societas Orientalis Fennica.

RäsÄNEN, Martti 1969. Versuch eines etymologisches Wörterbuchs der Türksprachen. [Lexica Societatis FennoUgricae 17.1.] Helsinki: Suomalais-Ugrilainen Seura.

SchöNIG, Claus 1984. Hilfsverben im Tatarischen. Untersuchungen zur Funktionsweise einiger Hilfsverbverbindungen. [Akademie der Wissenschaften und der Literatur, Mainz, Veröffentlichungen der Orientalischen Kommission 35.] Wiesbaden: Franz Steiner.

Sevortjan, Ervand Vladimirovič [Севортян, Эрванд Владимирович] (ред.) 1974. Этимологический словарь тюркских языков. Общетюркские и межтюркские основы на гласные. Москва: Издательство «Наука».

Somfai Kara, Dávid 2002. Kazak. [Languages of the World. Materials 417.] München: Lincom Europa. Somfai Kara, Dávid 2003. Kyrgyz. [Languages of the World. Materials 423.] München: Lincom Europa. Sulımowicz, Józef 1972. 'Materiał leksykalny krymskokaraimskiego zabytku językowego (druk z 1734 r.).' Rocznik Orientalistyczny 35/1: 37-76. 
SuLIMowicz, Józef 1973. 'Materiał leksykalny krymskokaraimskiego zabytku językowego (druk z 1734 r.). II.' Rocznik Orientalistyczny 36/1: 47-107.

Šč ŁrвAк, Aleksandr Michajlovič [Щербак, Александр Михайлович] 1970. Сравнительная фонетика тюркских языков. Ленинград: Издательство «Наука». Ленинградское отделение.

TatRussS (1966) = Golovkina 1966.

TatRussS (2004) = Ganiev 2004 .

Tekin, Talat 1994. 'Türk Dillerinde Önseste $y$ - Türemesi.' Türk Dilleri Araşttrmaları 4: 51-66.

Tenišev, Edchjam Rachimovič [Тенишев, Эдхям Рахимович] 1984. Сравнительно-историческая грамматика тюркских языков. Фонетика. Москва: Издательство «Наука».

TTDS (1969) = Machmutova 1969.

Wurm, Stefan 1949. ‘The (Kara-)Kirghiz Language.' BSOAS 13/1: 97-120.

Wurm, Stefan 1959. 'Das Özbekische.' In: Jean Deny, Kaare Grønbech, Helmuth Scheel and Zeki Velidi Togan (eds.) Philologiae Turcicae Fundamenta. Vol. 1. Wiesbaden: Franz Steiner, 489-524.

ZajĄCZкошsкI, Ananiasz 1931. Krótki wykład gramatyki języka zachodnio-karaimskiego (narzecze łuckohalickie). Łuck: Aleksander Mardkowicz.

ZAJĄCZKOWsKI, Ananiasz 1932. Sufiksy imienne i czasownikowe w języku zachodniokaraimskim (przyczynek do morfologii języków tureckich). [Prace Komisji Orjentalistycznej Polskiej Akademji Umiejętności 15.] Kraków: Polska Akademia Umiejętności.

ZajĄCzкоwski, Ananiasz 1939. 'Najstarsza wiadomość o języku tureckim Karaimów w Polsce (z XVII w.). Myśl Karaimska 12 (1937-1938): 90-99.

ZAJĄCZKowsKi, Ananiasz 1954. Słownik arabsko-kipczacki z okresu Państwa Mameluckiego. Bulġat al-muštāq fì luggat at-turk wa-l-qifžāa. Część II. Verba. Warszawa: Państwowe Wydawnictwo Naukowe.

Open Access. This is an open-access article distributed under the terms of the Creative Commons Attribution-NonCommercial 4.0 International License (https://creativecommons.org/licenses/by-nc/4.0/), which permits unrestricted use, distribution, and reproduction in any medium for non-commercial purposes, provided the original author and source are credited, a link to the CC License is provided, and changes - if any are indicated. 